\title{
Edukasi Infeksi Menular Seksual Pada Pedagang di Daerah Wisata
}

\author{
Halia Wanadiatri, Musyarrafah*, Aena Mardiah, Rusmiatik \\ Program Studi Pendidikan Dokter, Fakultas Kedokteran, Universitas Islam Al-Azhar, Mataram, Indonesia
}

\section{Article history}

Received: 16 Oktober 2019

Revised: 22 Oktober 2019

Accepted: 28 November 2019

*Corresponding Author:

Musyarrafah,

Fakultas Kedokteran,

Universitas Islam Al-Azhar,

Mataram, Indonesia;

Email:

musyarrafah.efa@gmail.com

\begin{abstract}
Sexually transmitted infections (STIs) or venereal diseases are one of the reproductive health issues that are currently in the top 10 infectious diseases in several developing countries, such as in Indonesia. This type of infectious disease has a high risk in tourist areas due to its strong tendency for spreading the disease. This study aims to enhance the awareness and the understanding of the STI of traders in the tourist area, Nipah Beach, North Lombok Regency. The methods that are used counseling and education, and discussion. The result of the study shows after the implementation of this activity, the traders have a better understanding of STIs and they can apply reproductive health to individuals, families, and the tourist environment.
\end{abstract}

Keywords: health; HIV/IADS; education; STI; tourism

Abstrak: Infeksi Menular Seksual (IMS) merupakan salah satu masalah kesehatan reproduksi yang saat ini masih menjadi penyakit infeksi dengan peringkat 10 besar di negara berkembang, termasuk Indonesia. Penyakit menular ini memiliki risiko tinggi terjadi di daerah wisata, karena potensi penyebaran penyakitnya sangat besar. Kegiatan ini bertujuan untuk meningkatkan kesadaran dan pemahaman mengenai IMS para pedagang di daerah wisata, Pantai Nipah, Kabupaten Lombok Utara. Metode yang digunakan adalah penyuluhan dan edukasi, serta diskusi. Setelah dilaksanakannya kegiatan ini para pedagang memiliki tingkat pengetahuan yang lebih baik mengenai IMS dan mampu menerapkan kesehatan reproduksi baik pada individu, keluarga dan lingkungan wisata.

Kata Kunci: kesehatan; HIV/AIDS; penyuluhan; IMS; pariwisata

\section{PENDAHULUAN}

Menurut Wolrd Health Organization (WHO), kesehatan reproduksi merupakan keadaan sehat yang menyeluruh, meliputi aspek fisik, mental, dan sosial, serta tidak adanya penyakit atau gangguan di segala hal yang berkaitan dengan sistem reproduksi tersebut (Glasier et al., 2006). Salah satu masalah kesehatan reproduksi adalah infeksi menular seksual (IMS) yang timbul atau ditularkan melalui hubungan seksual dengan manifestasi klinis berupa timbulnya kelainan-kelainan terutama pada alat kelamin (Harianti dan Nurbaiti, 2017). Saat ini IMS masih merupakan masalah kesehatan masyarakat dunia, baik di negara maju (industri) maupun di negara berkembang.

Pengendalian IMS merupakan prioritas utama WHO karena menjadi salah satu infeksi yang menempati peringkat 10 besar di negara berkembang, termasuk Indonesia. Data terbaru dari WHO menunjukkan bahwa lebih dari 1 juta orang yang didiagnosa IMS setiap harinya (World Health Organization, 2018). Berdasarkan data dari Kementerian Kesehatan Republik Indonesia Tahun 2015 
(Kemenkes RI) bahwa hampir 500 juta kasus baru IMS terjadi setiap tahun di seluruh dunia, diantaranya sifilis yang meningkatkan risiko tertular HIV sampai 300 kali lipat, gonore yang menyebabkan infertilitas, bayi lahir cacat akibat sifilis serta infeksi human papilloma virus (HPV) sebagai pencetus kanker mulut rahim (Kementerian Kesehatan Direktorat Jenderal Pengendalian Penyakit dan Penyehatan Lingkungan, 2015). Oleh karena itu, pengendalian IMS sudah seharusnya menjadi program yang dilaksanakan dengan kolaborasi antara pemerintah maupun pihak swasta dan masyarakat umum.

Data Profil Kesehatan Indonesia Tahun 2018 menunjukkan jumlah kasus baru HIV di Provinsi Nusa Tenggara Barat (NTB) mencapai 192 kasus dengan persentase klien positif HIV yaitu 0,56\% (Kemenkes RI, 2018). Angka ini masih terbilang rendah dari angka rerata Indonesia sekitar 1,52\% namun upaya pengendalian harus terus ditingkatkan agar IMS dapat diminimalisir terutama pada daerah destinasi wisata seperti NTB, khususnya di Pulau Lombok. Sebagai salah satu daerah pariwisata, kunjungan wisatawan domestik maupun mancanegara di Pulau Lombok terus bertambah dengan target kunjungan wisatawan sebanyak 4 juta orang pada tahun 2019. Penelitian oleh Wirakusuma et al., 2014 menunjukkan bahwa kunjungan pasien di Poliklinik Kulit RSUP Sanglah dalam kurun waktu 3 tahun meningkat, 3,05\% diantaranya adalah pasien IMS. Faktanya bahwa proporsi kejadian IMS di daerah wisata lebih tinggi dibandingkan dengan daerah bukan destinasi wisata.

Berdasarkan Peraturan Menteri Kesehatan Republik Indonesia, Permenkes No.74 Tahun 2015 tentang Upaya Peningkatan Kesehatan dan Pencegahan Penyakit bahwa salah satu bentuk promosi kesehatan terhadap IMS yaitu diselenggarakan melalui pemberdayaan masyarakat untuk menciptakan kesadaran, kemauan, serta kemampuan individu, keluarga, dan kelompok masyarakat dalam rangka meningkatkan kepedulian dan peran aktif upaya kesehatan untuk memelihara dan meningkatkan kesehatan (Kemenkes RI, 2015). Hal ini dapat dilakukan melalui pendekatan edukatif dan partisipatif seperti pengenalan terhadap penyakit-penyakit yang tergolong kelompok IMS dan upaya pencegahannya guna mencapai derajat kesehatan reproduksi yang paripurna.

Masyarakat di daerah pariwisata, khususnya pada pesisir Pantai Nipah, Dusun Nipah, Kecamatan Pemenang, Kabupaten Lombok Utara masih kurang mendapatkan informasi dan pengetahuan mengenai IMS baik dari etiologi, patofisiologi, upaya preventif hingga penanganan IMS di lingkungan keluarga. Kegiatan pengabdian ini bertujuan agar masyarakat lebih menyadari dan mendapatkan pemahaman mengenai IMS serta mampu memberikan edukasi kepada keluarga mengenai pengendalian IMS sehingga dapat menerapkan kesehatan reproduksi yang baik dan benar

\section{METODE}

Kegiatan ini dilakukan dengan metode penyuluhan dan edukasi serta diskusi. Cegah infeksi menular seksual adalah topik penyuluhan yang dipilih untuk disampaikan pada kegiatan ini. Selanjutnya, evaluasi kegiatan ini dilakukan melalui 2 tahap. Pada tahap pertama, penyebaran kuesioner yang berisi pertanyaan mengenai materi penyuluhan kepada partisipan sebanyak 25 orang. Hal ini bertujuan untuk mengetahui pengetahuan dan pemahaman awal masyarakat mengenai penyuluhan dan edukasi yang diberikan. Pada tahap kedua, dilakukan evaluasi dengan kuesioner yang sama setelah diberikan penyuluhan dan diskusi. Pada tahap ini, evaluasi bertujuan untuk mengetahui respon dan penguasaan materi yang telah diberikan. Tanggapan interaktif masyarakat saat penyampaian materi dan simulasi mengenai pencegahan IMS menjadi tolak ukur untuk melihat 
penguasaan materi penyuluhan. Skala perhitungan skor pengetahuan berdasarkan (Pangaribuan and Mardiah, 2017).

\section{HASIL DAN PEMBAHASAN}

Kegiatan pengabdian ini dilaksanakan pada tanggal 29 Juli 2019 bertempat di Dusun Nipah, Desa Nipah, Kecamatan Pemenang, Kabupaten Lombok Utara. Partisipan yang terlibat pada kegiatan pengabdian kali ini adalah pedagang ikan bakar di pesisir Pantai Nipah yang mayoritas perempuan, berprofesi sebagai juru masak dan penyaji makanan khas Lombok. Edukasi mengenai IMS kepada para pedagang, khususnya kalangan juru masak dan penyaji makanan ini merupakan kegiatan pertama dalam bentuk promosi kesehatan mengenai penyakit menular.

Upaya ini dilakukan untuk meningkatkan pengetahuan pedagang mengenai bahaya penyakit menular seksual, pencegahan penyebaran penyakit menular seksual, dan mampu mengubah sikap, perilaku dan kewaspadaan masyarakat terhadap penyebaran penyakit tersebut. Hasil pengukuran tingkat pengetahuan sebelum penyuluhan menunjukkan bahwa dari 25 orang responden, hanya sekitar $12 \%$ partisipan menjawab benar (Gambar 1). Rata-rata (mean) nilai tingkat pengetahuan awal responden adalah 64,40. Hal ini dapat dikatakan bahwa para pedagang di daerah wisata Pantai Nipah masih memiliki tingkat pengetahuan yang belum komprehensif mengenai IMS dan perlu mengenal lebih dekat mengenai penyakit menular tersebut.

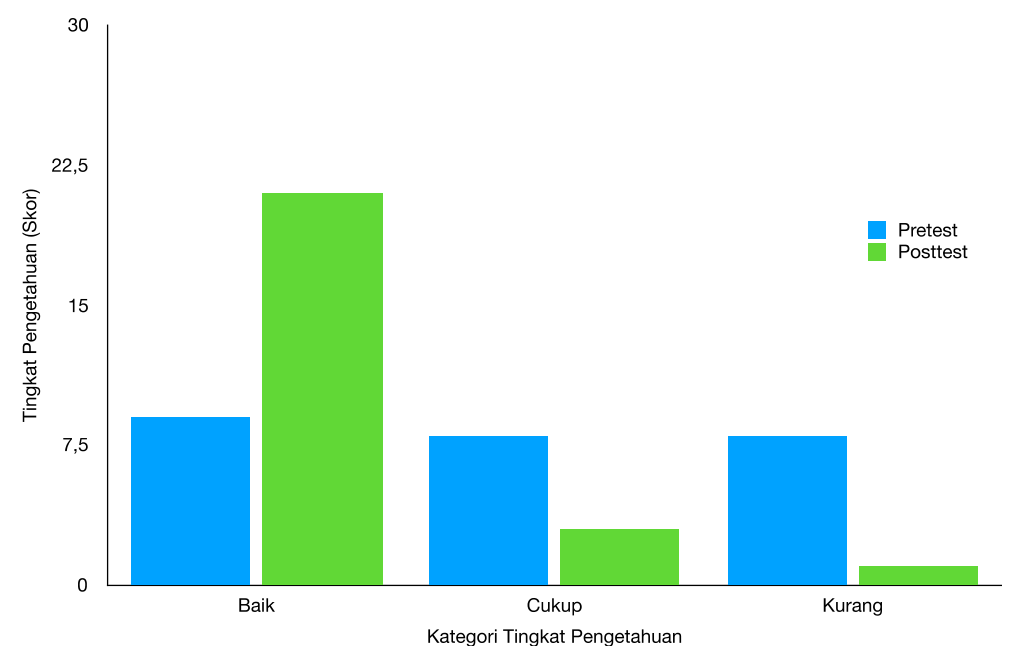

Gambar 1 Grafik perubahan tingkat pengetahuan para responden sebelum dan sesudah dilakukan penyuluhan dan edukasi mengenai IMS.

Tingkat pengetahuan adalah salah satu komponen penting dalam pembentukan sikap. Penelitian oleh Abhinaja and Astuti, 2013 menunjukkan bahwa terdapat korelasi kuat antara tingkat pengetahuan dengan sikap ibu rumah tangga terhadap IMS termasuk HIV/AIDS. Dengan demikian edukasi mengenai IMS terutama pada kaum ibu yang terlibat di daerah wisata menjadi hal yang sangat krusial dalam meningkatkan kesadaran masyarakat untuk mencegah penyebaran penyakit menular. Edukasi oleh tim pengabdi dilakukan secara interaktif sehingga para pedagang sangat antusias dalam menerima materi mengenai IMS dan ditampilkan gambaran penderita IMS melalui ilustrasi visual (Gambar 2). 

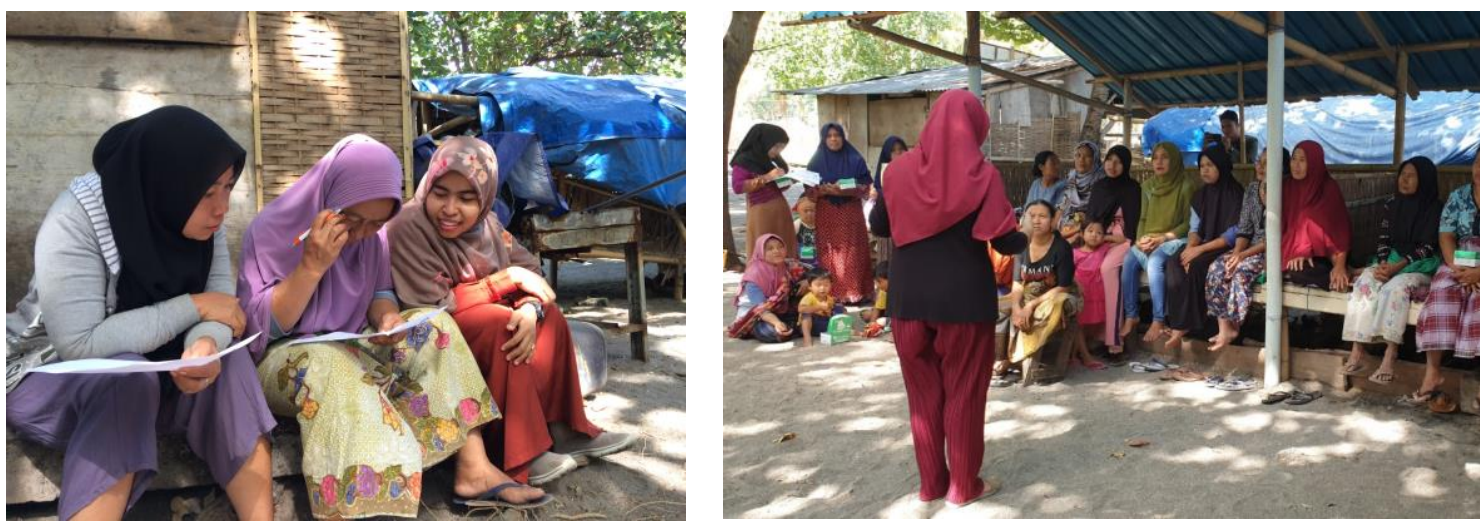

Gambar 2. Pengisian kuesioner oleh para pedagang sebelum dilakukan penyuluhan, didampingi oleh salah satu tim pengabdi (kiri); penyuluhan dan edukasi oleh dosen pakar dihadapan para pedagang di Pantai Nipah (kanan)

Salah satu sub kajian yang disampaikan adalah pencegahan gejala IMS pada saat hubungan seksual dengan suami menggunakan kondom. Para partisipan memberikan respon positif terhadap materi tersebut karena selama ini para pedagang tersebut masih menganggap penggunaan kondom adalah hal yang tabu ketika gejala IMS menyerang. Hal ini senada dengan hasil riset yang menyatakan bahwa sekitar $61,4 \%$ ibu rumah tangga tidak menerapkan perilaku pencegahan IMS termasuk HIV/AIDS dengan kondom. Salah satu faktor hal tersebuh dapat terjadi karena ibu rumah tangga merasa tidak melakukan perilaku berisiko berhubungan seks dengan pasangan dan malu mengatakan mengenai kesehatan reproduksi yang dialami (Abhinaja and Astuti, 2013).

Sasaran edukasi kali ini adalah para ibu pramusaji dan juru masak di daerah wisata memiliki tujuan strategis yaitu (1) para ibu mampu menjadi garda terdepan dalam menjaga keluarganya dari bahaya penularan IMS, sehingga keterbukaan komunikasi dalam keluarga harus diprakarsai oleh ibu. (2) Meningkatkan interaksi ibu dengan anak remaja nya untuk memberikan pemahaman mengenai IMS agar bisa terhindar dari perilaku berisiko terutama IMS dan kesehatan reproduksi. Melalui hal tersebut, orang tua dapat menyiapkan remaja untuk menjalankan kehidupan reproduksi yang sehat dan bertanggung jawab sebagai langkah awal pencegahan IMS di lingkungan rumah tangga. Hal ini sebagai bentuk dukungan salah satu program kesehatan reproduksi yang diintergrasikan kepada remaja melalui Program Kesehatan Remaja di Indonesia oleh Kemenkes sejak tahun 2003 (Harianti dan Nurbaiti, 2017).

Edukasi ini tidak hanya menargetkan pada kesadaran individual dan keluarga, tetapi turut memberikan efek terhadap lingkungan tempat bekerja yaitu daerah wisata. Diketahui bahwa daerah wisata dapat menjadi daerah transit penularan yang potensial untuk beberapa penyakit menular, termasuk risiko terjadinya penyakit menular antar manusia seperti Sexual Transmitted Disease (STD) sangat besar. Tingkat risiko yang bersifat global dalam menghadapi risiko kesehatan di daerah wisata menjadi perhatian semua lini termasuk penyedia jasa wisata sehingga dapat membentuk suatu sikap dan antisipasi menyeluruh dan terpadu (Djafri, 2009).

Setelah penyuluhan dan edukasi, responden diberi pertanyaan yang sama untuk melihat kemampuan para ibu-ibu pedagang menguasai materi mengenai IMS. Hasil evaluasi diperoleh bahwa dari 25 orang responden, terdapat 21 orang responden yang menjawab benar atau sekitar $81 \%$ dari total responden dengan rata-rata nilai 88,00 (Gambar 1). Hal ini menunjukkan bahwa terjadi peningkatkan pengetahuan pedagang di daerah wisata mengenai IMS dibandingkan dengan tingkat pengetahuan sebelum edukasi. Dengan demikian, pelaksanaan penyuluhan dan edukasi sangat efektif 
untuk membangun kesadaran masyarakat dalam mengenal penyakit-penyakit infeksi menular seksual, khususnya di daerah wisata.

Hasil pengabdian ini dapat memberikan sudut pandang yang baru bagi pemerintah daerah dalam membuat regulasi dan program intervensi sesuai sasaran dengan cara yang tepat sehingga angka proporsi IMS dapat diminimalisir, khususnya di daerah wisata

\section{Kesimpulan}

\section{KESIMPULAN DAN SARAN}

Kegiatan edukasi dan penyuluhan berjalan dengan lancar dan masyarakat memahami dan mampu mengenali IMS hingga upaya pengendaliannya sehingga dapat meningkatkan kesadaran pentingnya menjaga kesehatan reproduksi individu, keluarga maupun masyarakat.

\section{Saran}

Untuk kegiatan selanjutnya, perlu kolaborasi dengan pelayanan kesehatan setempat agar mampu mengidentifikasi angka kejadian IMS yang terjadi pada pelaku usaha di daerah wisata, khususnya di Dusun Nipah, Kecamatan Pemenang, Kabupaten Lombok Utara.

\section{Ucapan Terima Kasih}

Ucapan terima kasih kami sampaikan kepada pimpinan Fakultas Kedokteran Universitas Islam AlAzhar yang telah mendukung untuk pelaksanaan salah satu tri dharma perguruan tinggi. Tim dosen juga mahasiswa yang terlibat dalam kegiatan ini sehingga kegiatan pengabdian bisa berjalan lancar. Kepala Puskesmas Dusun Nipah beserta jajarannya yang telah menjadi mitra untuk pelaksanaan kegiatan di lingkungan wisata di Kabupaten Lombok Utara.

\section{DAFTAR PUSTAKA}

Abhinaja, I. G. W. and Astuti, P. A. S. (2013). Pengetahuan, Sikap Ibu Rumah Tangga Mengenai Infeksi Menular Seksual Termasuk HIV/AIDS Serta Perilaku Pencegahannya Di Kelurahan Sanur, Kecamatan Denpasar Selatan, Kota Denpasar Tahun 2013. Community Health, 1(3): 218-228.

Djafri, D. (2009). Manajemen Kesehatan Daerah Wisata. Jurnal Kesehatan Masyarakat, 3(1): 1-4.

Glasier, A, Gulmezoglu, AM, Schmid, GP, Moreno, CG, Van Look, PF. (2006) 'Sexual and reproductive health: a matter of life and death. Lancet, 368(9547): 1595-1607. doi: 10.1016/S0140-6736(06)69478-6.

Harianti, R, dan Nurbaiti, N. (2017). Karakteristik, Pengetahuan Dan Sikap Pasangan Usia Subur Tentang Penyakit Menular Seksual Di Klinik "Y" Kabupaten Indragiri Hulu. Jurnal Kesehatan Reproduksi, 7(3): 199-209.

Kemenkes RI. (2015). Permenkes No. 74 th 2015'. Jakarta: Kementerian Kesehatan RI, hal. 1-14. Available at: http://promkes.kemkes.go.id/permenkes-no74-tahun-2015-tentang-upayapeningkatan-dan-pencegahan-penyakit.

Kemenkes RI. (2018). Data dan Informasi Profil Kesehatan Indonesia 2018. Jakarta.

Kemenkes Direktorat Jenderal Pengendalian Penyakit dan Penyehatan Lingkungan, I. R. (2015). Buku Pedoman Nasional Tatalaksna IMS 2016, Pedoman Nasional Penanganan Infeksi Menular Seksual. Available at: http://siha.depkes.go.id/portal/files_upload/buku_pedoman_nasional_tatalaksna_ims_2016_ 


$$
\text { ok.pdf. }
$$

Pangaribuan, S. M. and Mardiah, W. (2017). Gambaran Tingkat Pengetahuan Wanita Pekerja Seks Komersial Tentang Infeksi Menular Seksual. Jurnal Pendidikan Keperawatan Indonesia, 3(2): 175. doi: 10.17509/jpki.v3i2.9423.

Wirakusuma, A.A.N.B.A., Darmada, I.G.K, Rusyati, L.M.M. (2014). Spektrum Infeksi Menular Seksual di Poliklinik Kulit dan Kelamin Rumah Sakit Umum Pusat Sanglah Periode 20092011 Bagian / SMF Ilmu Kesehatan Kulit dan Kelamin Fakultas Kedokteran Universitas Udayana / Rumah Sakit Umum Pusat Sanglah The spectrum of Sexual. E-Journal medika Udayana, 3(8): 1-7.

World Health Organization (2018). Report on global sexually trasnmitted infection surveillance, 2018, Geneva: World Health Organization. Available at: http://apps.who.int/iris. 